Images in...

\title{
Unusual cause of small bowel obstruction in an autistic child
}

\author{
Aoife Singh, Subramanian Ganesan, Suchandra Pande, Arani V Sridhar \\ Children's Hospital, Leicester Royal Infirmary, University Hospitals of Leicester NHS Trust, Leicester, UK \\ Correspondence to Dr Arani V Sridhar, arani.sridhar@uhl-tr.nhs.uk, sa135@le.ac.uk
}

\section{DESCRIPTION}

A 10-year-old girl with a background of global developmental delay and autism was admitted to our hospital with vomiting for 10 days. She had not opened her bowels for 5 days. Owing to her developmental delay she was unable to communicate verbally. Examination was unremarkable, including her abdomen which was soft with no distension and no masses felt. Her routine blood tests including full blood count, urea, creatinine, electrolytes, liver function tests and amylase levels were in the normal range. C-reactive protein (CRP) was less than 5. Blood cultures and urine cultures showed no growth. She was clinically diagnosed as a viral gastritis and started on intravenous fluids and ranitidine.

Two days after her admission, her vomiting was noted to be bilious and she had an abdominal x-ray (figure 1), abdominal ultrasound scan and paediatric surgical review.

The ultrasound scan demonstrated gross faecal loading and her presentation was now attributed to constipation. On laxative treatment she was opening bowels daily.

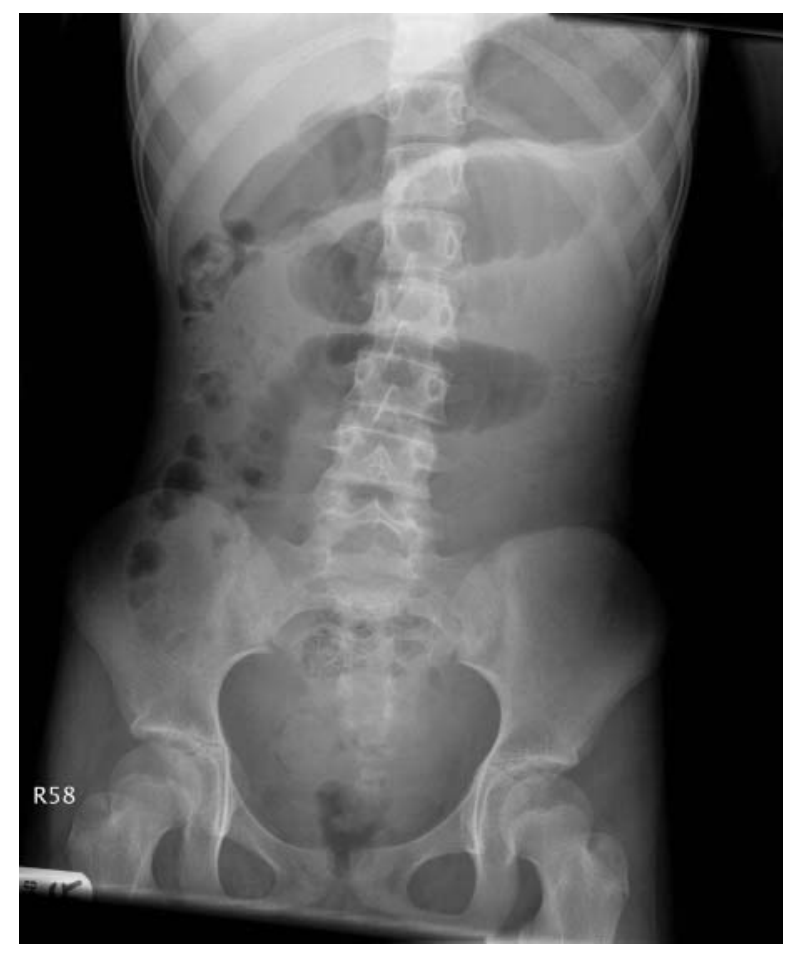

Figure 1 Abdominal radiograph demonstrating dilated small bowel with mucosal oedema in the right iliac fossa.
However, she persisted with intermittent bilious vomiting. The abdominal examination again revealed soft nondistended abdomen with normal bowel sounds. Initial digital rectal examination on day 3 of admission showed no significant abnormalities. As she was opening bowels regularly with no abdominal distension and normal bowel sounds, the paediatric surgical team did not consider bowel obstruction as the cause for her bilious vomiting.

However, 9 days after her admission, in view of the persistence of intermittent bile-stained vomiting, the patient had a CT scan of the abdomen (figure 2) that revealed a distal small bowel obstruction secondary to a Bezoar. On further questioning the patient's mother revealed that she often had a tendency to swallow non-edible objects. The patient underwent a laparotomy which revealed a partial distal small bowel obstruction due to a whole rubber glove. She made a good recovery and was discharged home 2 days postoperatively. This is an unusual clinical presentation of subacute partial small intestinal obstruction. The diagnosis was delayed as she had no classical signs of intestinal obstruction except for intermittent bile-stained vomiting.

Although ingestion of foreign bodies is relatively common in developmentally delayed and autistic children, they do not present with intestinal obstruction due to the small size of the ingested objects. In most cases the

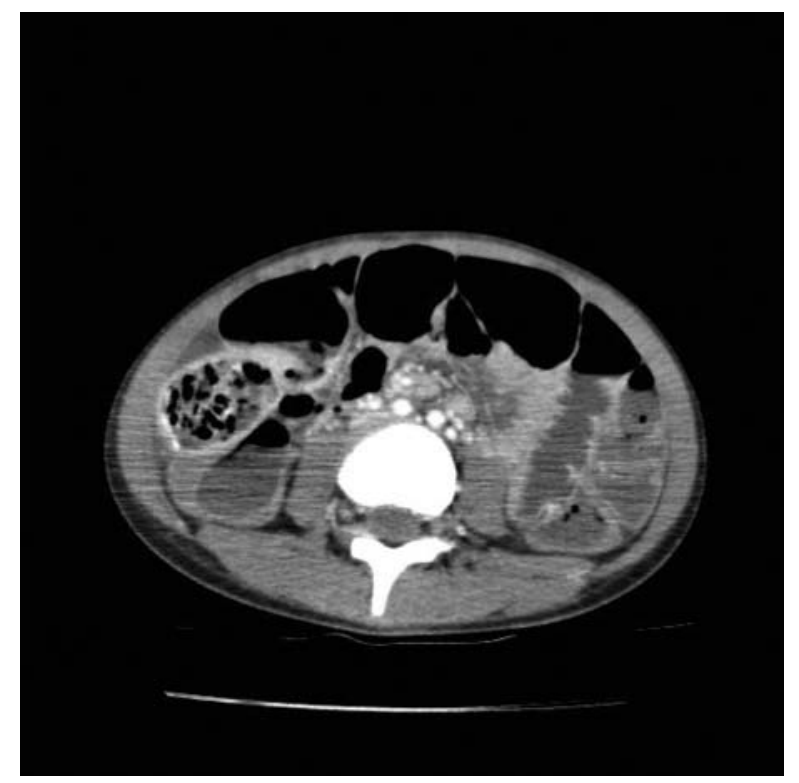

Figure 2 Abdominal CT scan demonstrating distal small bowel obstruction secondary to a bezoar. 


\section{BMJ Case Reports}

ingested objects are passed in stools with some patients requiring endoscopic removal depending on the location of the foreign object. Small bowel obstruction secondary to a Bezoar is rare but it is important to elicit a history of pica in children who are potentially at risk, for example those who are developmentally delayed and autistic children. ${ }^{1-3}$

Ingestion of whole rubber glove as the cause for small bowel obstruction in autistic children has been rarely reported. This case highlights that in children presenting with bilious vomiting, a surgical cause must be sought and ruled out.
Contributors All the authors have contributed in patient management. Competing interests None.

Patient consent Obtained.

\section{REFERENCES}

1. Verstocken A, Himpens J, Leman G. An unusual case of small bowel obstruction. Acta Chir Belg 1996:96:168-9.

2. Conyers R, Efron D. Agitation and weight loss in an autistic boy. $J$ Paediatr Child Health 2007:43:186-7.

3. Serour F, Witzling M, Frenkel-Laufer D, et al. Intestinal obstruction in an autistic adolescent. Pediatr Emerg Care 2008;24:688-90.

This pdf has been created automatically from the final edited text and images.

Copyright 2012 BMJ Publishing Group. All rights reserved. For permission to reuse any of this content visit http://group.bmj.com/group/rights-licensing/permissions.

BMJ Case Report Fellows may re-use this article for personal use and teaching without any further permission.

Please cite this article as follows (you will need to access the article online to obtain the date of publication).

Singh A, Ganesan S, Pande S, Sridhar AV. Unusual cause of small bowel obstruction in an autistic child. BMJ Case Reports 2012;10.1136/bcr-2012-006400, Published XXX

Become a Fellow of BMJ Case Reports today and you can:

- Submit as many cases as you like

- Enjoy fast sympathetic peer review and rapid publication of accepted articles

Access all the published articles

- Re-use any of the published material for personal use and teaching without further permission

For information on Institutional Fellowships contact consortiasales@bmjgroup.com

Visit casereports.bmi.com for more articles like this and to become a Fellow 